\title{
Epidemiology of Diseases Caused by Xylella fastidiosa in California: Evaluation of Alfalfa as a Source of Vectors and Inocula
}

\author{
Mark S. Sisterson, United States Department of Agriculture-Agricultural Research Service (USDA-ARS), San Joa- \\ quin Valley Agricultural Sciences Center, Parlier, CA 93648; Shyamala R. Thammiraju, Department of Environ- \\ mental Science, Policy and Management, University of California, Berkeley 94720-3114; Kris Lynn-Patterson, \\ Division of Agriculture and Natural Resources, University of California, Kearney Agricultural Center, Parlier 93648; \\ Russell L. Groves, USDA-ARS, San Joaquin Valley Agricultural Sciences Center; and Kent M. Daane, Department \\ of Environmental Science, Policy and Management, University of California, Berkeley
}

\begin{abstract}
Sisterson, M. S., Thammiraju, S. R., Lynn-Patterson, K., Groves, R. L., and Daane, K. M. 2010. Epidemiology of diseases caused by Xylella fastidiosa in California: Evaluation of alfalfa as a source of vectors and inocula. Plant Dis. 94:827-834.

Pierce's disease and almond leaf scorch disease have been chronic problems for California grape and almond growers, respectively. Both diseases are caused by the xylem-limited, bacterial pathogen Xylella fastidiosa, which is transmitted by xylem-feeding insects. We evaluated the potential for alfalfa to serve as a source of vectors and inocula in California. Analysis of Geographic Information Systems maps on the distribution and abundance of grape, almond, and alfalfa plantings determined that 94,521 ha of almond and grape were planted within $1.6 \mathrm{~km}$ of an alfalfa field. Seasonal trends of $X$. fastidiosa detection were monitored outdoors and in the greenhouse in five needle-inoculated alfalfa cultivars (CUF101, Moapa69, WL342, WL530HQ, and WL625HQ) over 2 years. Results suggest that cool winter temperatures reduced X. fastidiosa populations to undetectable levels but did not eliminate infections. Sampling of alfalfa fields to assess incidence of $X$. fastidiosa corroborated this result, with positive samples detected in summer only. Incidence of X. fastidiosa in alfalfa during summer was low, with only 6 positive samples out of 1,156 samples collected over 3 years. Insect trapping in alfalfa fields over 3 years found that the green sharpshooter (Draeculacephala minerva) was the most abundant vector. Within alfalfa fields, green sharpshooter abundance was highest in weedy areas, suggesting a preference for weeds over alfalfa. These results confirm that weedy alfalfa fields can serve as an important source of vectors. Incidence of X. fastidiosa in alfalfa was low, possibly due to preference of vectors for weeds over alfalfa.
\end{abstract}

Nearly $50 \%$ of U.S. fruit and nut crops are grown in California (7). Within California, grape is the top-valued fruit crop, with 343,173 ha planted in 2007 (9), and almond is the top-valued nut crop, with 299,467 ha in 2007 (6) that accounted for $80 \%$ of the world's almond production (8). Both crops are impacted by diseases caused by the xylem-limited bacterium

Corresponding author: M. S. Sisterson

E-mail: mark.sisterson@ars.usda.gov

Current address of R. L. Groves: Department of Entomology, University of Wisconsin, Madison 53706.

Mention of proprietary or brand names are necessary to report factually on available data; however, the USDA neither guarantees nor warrants the standard of the product, and the use of the name by USDA implies no approval to the exclusion of others that also may be suitable.

Accepted for publication 7 April 2010.

doi:10.1094/PDIS-94-7-0827

This article is in the public domain and not copyrightable. It may be freely reprinted with customary crediting of the source. The American Phytopathological Society, 2010.
Xylella fastidiosa Wells et al.; namely, Pierce's disease of grape and almond leaf scorch disease of almond (31). Strains of $X$. fastidiosa are variable (23) and not all strains cause Pierce's disease or almond leaf scorch disease (2). The pathogen is transmitted by xylem-sap-feeding insects, predominately sharpshooters $(46,49)$. Recent outbreaks of Pierce's disease in California were due to the invasive glassywinged sharpshooter, Homalodisca vitripennis (Germar) (10,43). However, Pierce's disease and almond leaf scorch disease have an episodic history in California that predates the arrival of the glassy-winged sharpshooter $(24,25,47)$ and were, instead, associated with native vectors (25).

Understanding the epidemiology of diseases caused by $X$. fastidiosa in California requires understanding the distribution of: (i) affected crops, (ii) reservoir habitats for insect vectors, and (iii) reservoir host plants of $X$. fastidiosa, which vary by region in California (52). On the north coast, the affected commodity is grape. In this area, the key vector is the blue-green sharpshooter, Graphocephala atropunctata (Signoret), which resides in riparian habi- tats that border vineyards (40). In California's Central Valley, grape and almond are affected. For much of the Central Valley, the key vectors appear to be the green sharpshooter, Draeculacephala minerva Ball, and the less common red-headed sharpshooter, Xyphon fulgida Nottingham (21). Diseased vines and trees are typically found near alfalfa fields or permanent pastures, habitats known to harbor green sharpshooter populations (42). Finally, in southern portions of the Central Valley and in Southern California, grape is the primarily affected crop, the glassy-winged sharpshooter is the key vector, and citrus is a key host plant for this sharpshooter (39).

Of all potential habitats that may serve as a source of vectors or inocula, alfalfa (Medicago sativa L.) has the longest history of association with Pierce's disease in California. From 1929 to 1950, alfalfa was affected by alfalfa dwarf (53), a disease presumed, early on, to be caused by the same agent as Pierce's disease (27). Consequently, alfalfa was implicated as a source of inocula (26) for a 1935-to-1941 Pierce's disease epidemic in California $(24,25)$. During this period, the relationship of alfalfa with diseases caused by Xylella fastidiosa received a fair amount of attention (26,27,53-55). However, as problems associated with alfalfa dwarf dwindled in the latter half of the 1900 s, so too did research on the epidemiological significance of alfalfa.

In light of recent Pierce's disease epidemics in California, there is renewed interest in understanding the role alfalfa may play in the spread of $X$. fastidiosa. Such a reevaluation is warranted for many reasons. First, much of the research assessing the relationship of alfalfa dwarf with Pierce's disease was completed before $X$. fastidiosa was identified as the causal agent $(16,56)$. Consequently, tools are currently available that were not available in the early part of the 1900s. Second, alfalfa dwarf has not been viewed as a problem in California for nearly 60 years (20), suggesting that the epidemiological role of alfalfa may have changed. Finally, host records for the glassy-winged sharpshooter indicate that it can use alfalfa as a host (30). Thus, a better understanding of 
the potential role of alfalfa could be valuable if the glassy-winged sharpshooter expanded its range in California.

To assess the role of alfalfa in the epidemiology of diseases caused by $X$. fasGeographic Information Systems (GIS) maps on the distribution of alfalfa, grape, and almond in California. These maps were used to estimate the degree of overlap in the distribution of almond and grape with alfalfa. Second, alfalfa was needle inoculated to determine the seasonal fate of $X$. fastidiosa in alfalfa in the field. Third, alfalfa fields were sampled to estimate seasonal incidence of $X$. fastidiosa. Finally, vector abundance and distribution in alfalfa fields was assessed.

\section{MATERIALS AND METHODS}

Proximity of alfalfa to almond and grape. Movement of native vectors ( $D$. minerva and Xyphon fulgida) is generally described as local (25). As a result, the distance between alfalfa fields and almond tidiosa in California, we first analyzed

or grape plantings is likely to affect the probability that vectors move between alfalfa fields and one of the susceptible crops. Thus, defining where in California alfalfa coincides with almond and grape and quantifying the proximity of these crops is critical to evaluating the potential for alfalfa to serve as a source of vectors or inocula. To accomplish this, GIS maps on the distribution of alfalfa, almond, and grape were analyzed. The maps were generated from data compiled by the State of California Pesticide Use Reports during 2006 (4). Briefly, when a grower treats a field with a pesticide in California, the grower must submit documentation to the Department of Pesticide Regulation on crop treated, area treated, and location of the treated field as identified by $1.6 \mathrm{~km}^{2}$ sections based on the Public Land Survey System (5). A limitation of these maps is that fields are omitted if no pesticides are applied during the course of the year. Estimates from these maps of total area planted to each crop at the county level
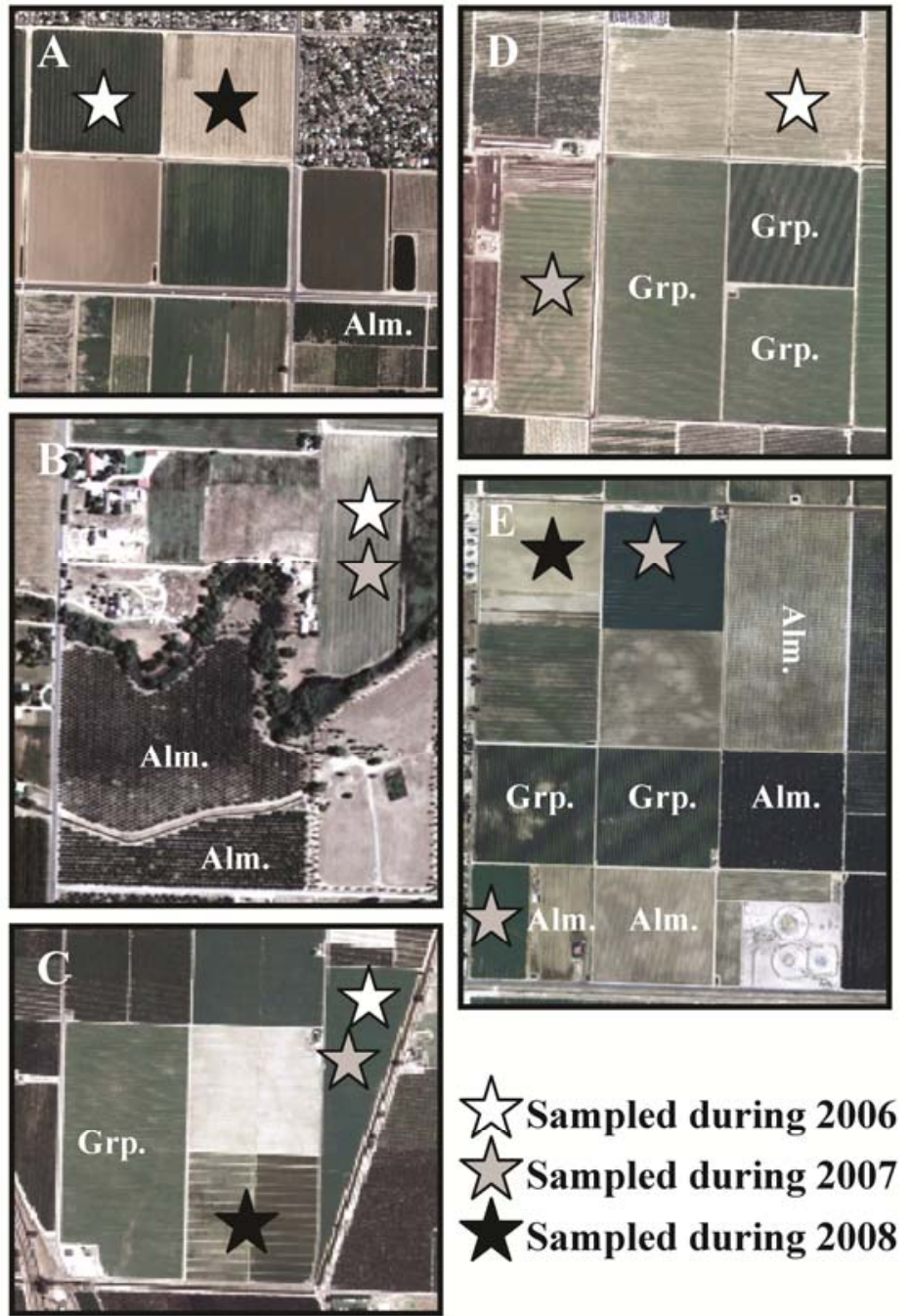

Fig. 1. Location of field sites and years sampled. A, Fields sampled at site A and proximity to an almond orchard. B, Fields sampled at site B and proximity to almond orchards. C, Fields sampled at site $\mathrm{C}$ and proximity to a vineyard. D, Fields sampled at site D and proximity to vineyards. E, Fields sampled at site E and proximity to almond and grape. Two fields were sampled at site E in 2007 (site E-1 and E-2). Alm. = almond and Grp. = Grape. were similar to those reported by the $\mathrm{Na}$ tional Agricultural Statistics Service (3).

To determine where in California alfalfa coincides with almond and grape, the hectares of alfalfa, almond, and grape cultivated in each county in California were determined. Next, the hectares of almond and grape plantings that were within 1.6 $\mathrm{km}$ of an alfalfa field were determined by summing the hectares of almond and grape that were present within sections that also grew alfalfa. This level of spatial resolution $(1.6 \mathrm{~km})$ was chosen because it was the smallest scale possible due to construction of the maps based on the Public Land Survey System.

Seasonal fate of Xylella fastidiosa in alfalfa. Studies with grape have shown that Xylella fastidiosa populations are greatest in summer and fall and lowest in winter and spring (28). Acquisition may be dependent on X. fastidiosa population (29); therefore, seasonal changes in $X$. fastidiosa population could affect the time of year that alfalfa may serve as a source of inoculum. Additionally, studies with grape and almond suggest that cool winter temperatures can eliminate infections $(17,34,41)$. Thus, effects of cool winter temperatures on infections in alfalfa were assessed over a 2-year period following needle inoculations. To accomplish this, five cultivars of alfalfa (CUF101, Moapa69, WL342, WL530HQ, and WL625HQ) were needle inoculated. The number of needleinoculated plants per cultivar varied from 12 to 24 plants. Plants were grown from seed in 3.8-liter pots using Sunshine Soil Mix 1 and were approximately 8 weeks old at the time of first inoculation. Inoculations took place on two dates, 20 July and 20 August 2007. On the first date, three stems per plant were inoculated and, on the second date, two stems per plant were inoculated, for a total of five inoculated stems per plant. Inoculated stems were marked with colored tape. Stems were inoculated by placing a $15-\mu \mathrm{l}$ drop of $X$. fastidiosa suspension on the base of a stem and then piercing the stem with a 23-gauge hypodermic needle. The M23 strain of $X$. fastidiosa was used for all inoculations. This strain causes Pierce's disease and almond leaf scorch disease and belongs to the grape genetic group $(2,12,13)$. Half of the plants were held in a screen cage during the first winter and were exposed to ambient winter temperatures in Parlier, CA (average low in December and January is $2.2^{\circ} \mathrm{C}$ ) and the other half were held in a greenhouse maintained at $27^{\circ} \mathrm{C}$. Plants held outdoors were removed from their pots and planted inside the screen cage. Plants held in the greenhouse were kept in pots. On 15 April 2008, plants held in the greenhouse were moved outdoors, removed from their pots, and planted in a screen cage adjacent to the screen cage that held the plants kept outdoors the previous winter. All plants were held outdoors 
for a second winter and kept until July 2009. During the course of the study, plants were pruned regularly. Whereas growers typically cut alfalfa every 28 days between April and October (38), a longer cut interval was used to ensure that infections were systemic and not eliminated via cutting. Accordingly, the average time period between cuttings was 106 days (minimum = 59 days, maximum $=173$ days).

Because growers routinely cut alfalfa, one possible mode of transmission in the field is through cutting. Thus, a secondary objective was to assess whether mechanical transmission was possible. This was assessed by maintaining an additional three to seven plants (split between the greenhouse and screen cage) of each cultivar under the same conditions as those in the seasonality study. These plants were not needle inoculated but were potentially inoculated by pruning them after needleinoculated plants with the same disinfested shears. To differentiate these plants from needle-inoculated plants, we refer to them as "test plants". A limitation of the experimental design used to evaluate mechanical transmission is emphasized. Specifically, all test plants were pruned with disinfested shears. Because true controls (uninoculated plants cut with cleaned shears) were not maintained, the possibility that infections in test plants were due to a mechanism other than mechanical transmission cannot be ruled out; thus, positive detections in test plants simply suggest that mechanical transmission may be possible.

Over the course of the study, all plants were assayed for the presence of $X$. fastidiosa every 2 to 4 months using standard polymerase chain reaction (PCR) methods (details provided below). On the first sampling date, two samples per needleinoculated plant were collected whereas only a single sample was collected from test plants. The two samples collected from needle-inoculated plants consisted of an inoculated stem (identified by the tape placed around the stem at the time of inoculation) and a randomly selected stem that was distant from the inoculation site. For test plants, the single sample consisted of a randomly selected stem. By the second sampling date, most needle-inoculated stems had died. Thus, for all remaining sampling dates, a single randomly selected stem was assayed (for needle-inoculated and test plants). For analysis, we differentiated between cultivars on the first sampling date only. Thereafter, results were pooled for all cultivars due to mortality over the 2 years of study.

Incidence of $X$. fastidiosa in alfalfa. Alfalfa fields were sampled in spring, summer, winter, and fall to estimate incidence of $X$. fastidiosa throughout the year. Five sites were used, two each in Fresno and Tulare Counties and one in Kern County, CA (Fig. 1). At each site, the same field was not sampled in all years of study because some growers rotated their field from alfalfa to another crop. If this occurred, a nearby replacement alfalfa field was selected (Fig. 1). Thus, site names refer to general locations but not exact fields, as follows: site A was sampled in 2006 in a block planted with WL575HQ and, in 2008, in a block planted with a mix of WL625HQ and PGI; site B was a single field planted with WL625HQ and sampled in 2006 and 2007; site C consisted of two fields planted with WL625HQ, the first sampled in 2006 and 2007 and the second sampled in 2008; site D fields were planted with WL625HQ and sampled in 2006 and 2007; and site E consisted of three fields planted with Tech Ag 944, two sampled in 2007 (E-1 and E-2) and the third sampled in 2008 (Fig. 1).

All sampled alfalfa fields were near almond or grape. Alfalfa fields in Fresno County (sites A and B; Fig. 1A and B) and Kern County (site E; Fig. 1E) were near almond orchards that were previously surveyed for almond leaf scorch disease (22,51). Specifically, 14, 3, and $3 \%$ of trees in at least one of the almond orchards near sites $\mathrm{A}, \mathrm{B}$, and $\mathrm{E}$ were affected by almond leaf scorch disease, respectively (51). Alfalfa fields in Tulare County (sites $\mathrm{C}$ and D; Fig. 1C and D) were near vineyards with a low incidence of Pierce's disease. Survey of these vineyards found that Pierce's disease was present but that incidence was low $<1 \%$ (M. S. Sisterson, unpublished data).

Sampling began in summer 2005 and continued through summer 2008, for a total of 13 sampling dates. Each field was separated into nine quadrats (three by three) and 5 to 22 alfalfa stems per quadrat were collected and screened for presence of $X$. fastidiosa using PCR-based methods (details provided below). In summer and fall 2005, 22 stems per quadrat were collected. From winter 2005 to winter 2006, 10 stems per quadrat were collected. From spring 2007 to project completion, five stems per quadrat were collected. In total, 3,849 plant samples were assayed with $801,1,156,821$, and 1,071 plant samples from spring, summer, fall, and winter, respectively.

Vector sampling in alfalfa. In each field site described above, a grid of 16 to 20 yellow sticky traps (14 by $22.9 \mathrm{~cm}$; Seabright Laboratories, Emeryville, CA) was placed out and replaced biweekly. There were 8 to 12 traps on field perimeters and 6 placed in field interiors. The number of green sharpshooters, red-headed sharpshooters, and glassy-winged sharpshooters on each trap was counted. Sampling began in January 2006 and was completed in November 2008. Data on insecticide use, irrigation, and cutting were also collected. Using analysis of variance, effects of county, year, number of irrigations, and number of cuttings on the sum of sharpshooter abundance in each field from February to October of each year were tested (48).

Site A was the only site located within a known glassy-winged sharpshooterinfested zone, and red-headed sharpshooters are known to be less abundant than green sharpshooters (21); therefore, we anticipated that green sharpshooters would be the most abundant vector in our samples. Thus, data to test hypotheses about the distribution of green sharpshooters in alfalfa fields were collected. Specifically, green sharpshooters have been shown to have higher abundance in weedy than weed-free alfalfa fields (42). Consequently, we tested the hypothesis that trap catches would be higher for traps located in weedy than weed-free sections of each alfalfa field. To facilitate this evaluation, the percentage of area covered with weeds within $3 \mathrm{~m}$ of each trap was estimated by visual rating in fall 2007 (8 November 2007), spring 2008 (27 May 2008), and fall 2008 (1 October 2008).

For analysis, we assessed whether the mean number of green sharpshooters caught per trap per year was higher for traps located on field perimeters than field interiors using a paired $t$ test. The role of weed ground cover on the aforementioned analysis was assessed by comparing weed ground cover surrounding traps on field perimeters to field interiors using a paired $t$ test. For all analyses involving weed assessments, trapping data from 2006 were omitted because weed assessments were not conducted during that year. Next, we assessed the effects of weed ground cover for each year-site combination using simple regressions of weed ground cover versus trap catch (48). Finally, to assess the effects of weed ground cover on trap catch across field sites, we regressed trap catch against site and weed ground cover nested within site. Partial residual plots were generated to view the effects of weed ground cover on trap catch with the effect of site removed (45).

DNA extraction and PCR. The first step of sample preparation differed over the 4 years of study. From summer 2005 through summer 2007, only field-collected alfalfa samples were assayed, and initial sample preparation involved lyophilizing $3.8 \mathrm{~cm}$ of stem tissue. Lyophilized tissue was placed into $2-\mathrm{ml}$ tubes with a ceramic bead and shaken for $90 \mathrm{~s}$ at a rate of 1,300 strokes/min using a model 2000 Geno/Grinder (SPEX Cetriprep Inc, Metuchen, NJ). Subsequently, $1 \mathrm{ml}$ of DNA extraction buffer was added (20 mM EDTA and $350 \mathrm{mM}$ Sorbitol in $100 \mathrm{mM}$ TrisHCL, pH 8.0, plus 2.5\% [wt/vol] PVP-40) and samples were centrifuged at 9,300 $\times g$ for $10 \mathrm{~min}$. The supernatant was discarded leaving a pellet. From fall 2007 to the completion of the experiment, there were field-collected samples, samples from needle-inoculated plants, and samples from test plants. During this period, whole 
stems were homogenized in 10-by-13-cm extraction bags with $5 \mathrm{ml}$ of extraction buffer using a Homex 6 Bioreba Ag Homogenizer (Bioreba Ag, Reinach, Germany). Homogenate $(2 \mathrm{ml})$ was removed and centrifuged at $9,300 \times g$ for $10 \mathrm{~min}$ and the supernatant discarded, leaving a pellet. All steps from the point of pellet formation were the same for both protocols and were similar to those used by Lin and Walker (35) and Francis et al. (19)

Pellets were resuspended in $300 \mu$ of DNA resuspension buffer $(20 \mathrm{mM}$ EDTA, 350 Sorbitol in $100 \mathrm{mM}$ Tris-HCL, $\mathrm{pH}$ 8.0) plus $300 \mu \mathrm{l}$ of lysis buffer $(50 \mathrm{mM}$ EDTA, $2 \mathrm{M} \mathrm{NaCl}$, and 2\% [wt/vol] cetyltrimethylammonium bromide in $200 \mathrm{mM}$ Tris-HCL, pH 8.0) and $200 \mu$ of $5 \%$ sarcosyl. Samples were mixed and incubated at $65^{\circ} \mathrm{C}$ for $45 \mathrm{~min}$. To purify DNA, $800 \mu \mathrm{l}$ of chloroform:isoamyl alcohol $(24: 1)$ was added and tubes centrifuged at 9,300 $\times g$ for $10 \mathrm{~min}$. The upper phase $(775 \mu \mathrm{l})$ of the centrifuged samples was transferred to a new tube containing $700 \mu \mathrm{l}$ of chloroform:octanol and centrifuged at 9,300 $\times g$ for $10 \mathrm{~min}$. Nucleic acid was precipitated by transferring the upper phase $(650 \mu \mathrm{l})$ of the centrifuged samples to a new tube containing $600 \mu \mathrm{l}$ of isopropanol and centrifuging at $9,300 \times g$ for $10 \mathrm{~min}$, and the pellet was rinsed with $70 \%$ ethanol. The DNA preparation was resuspended in 100 $\mu l$ of $1 \times$ Tris-EDTA buffer.

For PCR, samples were diluted 1:100 and $2 \mu \mathrm{l}$ of diluted sample was added to 2 $\mu \mathrm{l}$ of $10 \times$ buffer, $1.6 \mu \mathrm{l}$ of dNTP, $13.9 \mu \mathrm{l}$ of water, and $0.1 \mu \mathrm{l}$ of Taq Polymerase (Takara Bio inc., Otsu, Japan). To this, $0.2 \mu \mathrm{l}$ of each primer (RST 31 and RST 33) was added. Primers RST 31 and RST 33 are $X$. fastidiosa specific and amplify a 733-bp fragment (37). Amplification was completed using a PTC-200 Bio-Rad DNAEngine Peltier Thermal Cycler (Bio-Rad, Hercules, CA). Temperature cycling was
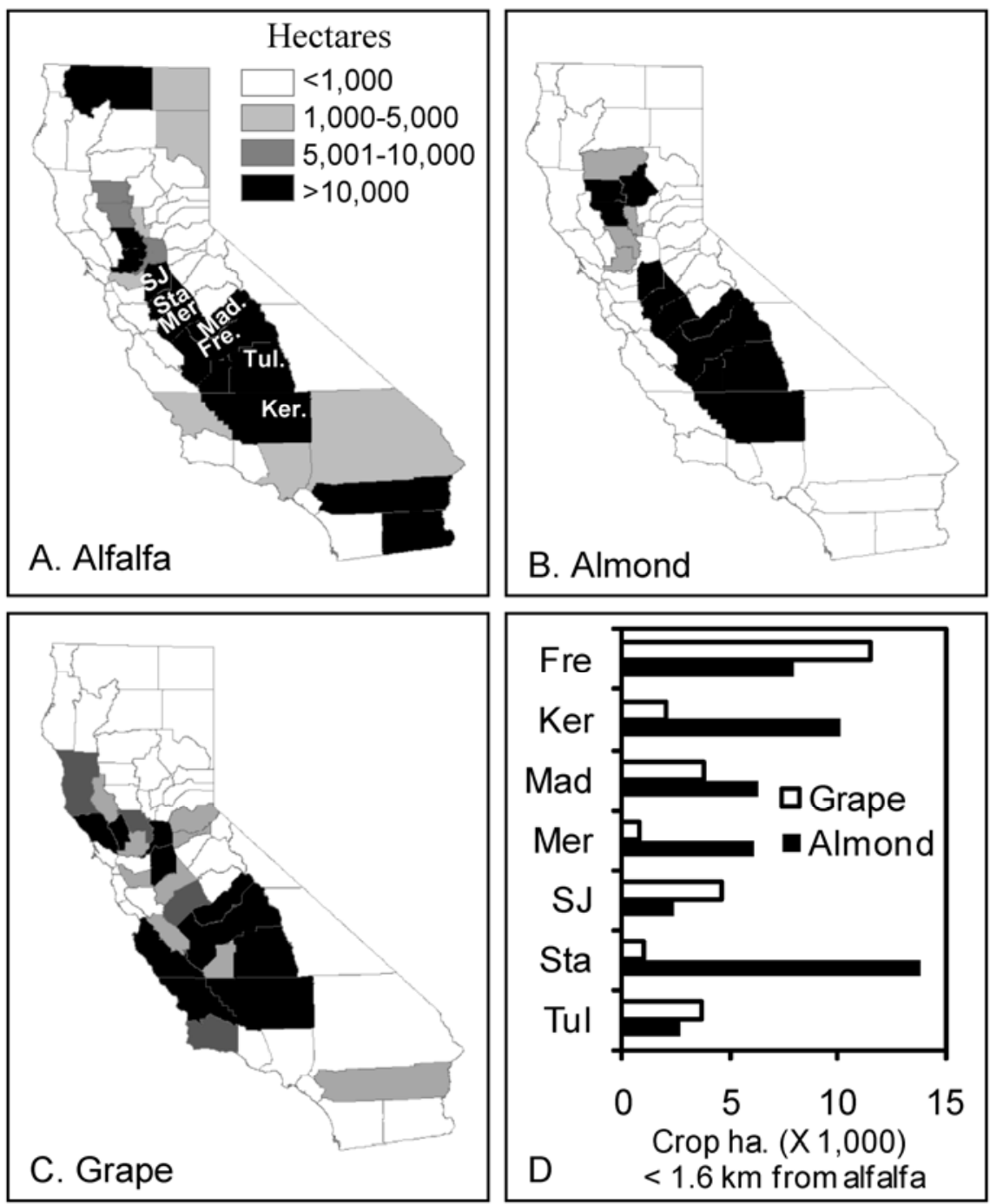

Fig. 2. Hectares planted to A, alfalfa; $\mathbf{B}$, almond; and $\mathbf{C}$, grape in California by county. Maps were generated using pesticide use reports from 2006. D, Number of hectares of almond or grape that were within $1.6 \mathrm{~km}$ of alfalfa in the seven counties with $>10,000$ ha of alfalfa and $>10,000$ ha of almond and grape combined. County names were abbreviated by their first three letters, except for counties with names consisting of two words, in which case the first two letters of each word were used (SJ $=\mathrm{San}$ Jose, Sta $=$ Stanislaus, Mer $=$ Merced, Mad $=$ Madera, Fre $=$ Fresno, Tul $=$ Tulare, and Ker $=$ Kern $)$. as follows: $94^{\circ} \mathrm{C}$ for $5 \mathrm{~min}$ followed by 40 cycles of $94^{\circ} \mathrm{C}$ for $30 \mathrm{~s}, 55^{\circ} \mathrm{C}$ for $40 \mathrm{~s}$, and $72^{\circ} \mathrm{C}$ for $45 \mathrm{~s}$. Electrophoresis was conducted on $2 \%$ agarose gels. Gels were stained with ethidium bromide and bands visualized under UV light.

\section{RESULTS}

Proximity of alfalfa to almond and grape. Of California's 58 counties, 7 counties simultaneously planted $>10,000$ ha of alfalfa and $>10,000$ ha of almond and grape combined (Fig. 2A-C; Fresno, Kern, Madera, Merced, San Joaquin, Stanislaus, and Tulare). For those seven counties there was a total of 76,813 ha ( $16 \%$ of almond and grape grown in those counties) of almond and grape planted within $1.6 \mathrm{~km}$ of an alfalfa planting (Fig. 2D). There was an additional 17,708 ha of almond and grape planted within $1.6 \mathrm{~km}$ of an alfalfa planting in the remaining California counties. Stanislaus County had the greatest area of almond planted in proximity to alfalfa, with 13,880 ha of almond within $1.6 \mathrm{~km}$ of an alfalfa planting. Fresno County had the greatest area of grape planted in proximity to alfalfa, with 11,523 ha of grape within $1.6 \mathrm{~km}$ of alfalfa. Fresno County also had the greatest area of both commodities combined in proximity to alfalfa, with 19,445 ha of almond and grape within 1.6 $\mathrm{km}$ of an alfalfa planting.

Seasonal fate of $X$. fastidiosa in alfalfa. Needle inoculations were successful for all cultivars tested. Molecular analyses conducted 47 days after the first inoculation documented a high frequency of positive detections at inoculation sites but a low frequency of positive detections away from inoculation sites (Fig. 3A). This suggests limited movement of $X$. fastidiosa within plants over 47 days. Specifically, $75,58,50,17$, and $11 \%$ of inoculated stems tested positive for $X$. fastidiosa for the cultivars WL342, Moapa 69, CUF101, WL625HQ, and WL530HQ, respectively (mean across cultivars $=44 \%$; Fig. $3 \mathrm{~A}$ ). In contrast, detection in stems distant from inoculation sites was lower, with $13,0,0$, 6 , and $0 \%$ of stems testing positive for cvs. WL342, Moapa 69, CUF101, WL625HQ, and WL530HQ, respectively (mean across cultivars $=4 \%$; Fig. $3 \mathrm{~A}$ ).

From 22 October 2007 to 14 April 2008, half of the plants were kept in a greenhouse and the other half were kept outdoors in a screen cage. In January and March 2008, 76 and $51 \%$ of needleinoculated plants held in the greenhouse tested positive for $X$. fastidiosa, respectively, whereas none of the needleinoculated plants held outdoors tested positive (Fig. 3A). On 14 April 2008, needle-inoculated plants held in the greenhouse were moved outdoors into a screen cage adjacent to the screen cage that held the needle-inoculated plants that were outdoors during the previous winter. Screening of needle-inoculated plants in 
July and October 2008 found that the percentage of $X$. fastidiosa-positive plants was similar for the two groups, suggesting that cool winter temperatures reduced infections to undetectable levels in needleinoculated plants held outdoors during the winter but did not eliminate infections (Fig. 3A). To reinforce this result, both sets of plants were held outdoors for an additional year. As for plants held outdoors in the previous year, no needle-inoculated plants tested positive for $X$. fastidiosa in February and April 2009 (Fig. 3A). However, screening of needle-inoculated plants in July 2009 found that $56 \%$ of plants that originated from the greenhouse group were positive for $X$. fastidiosa and that $64 \%$ of plants that were held outdoors during the entire course of the study were positive for $X$. fastidiosa.

Screening of test plants suggests that mechanical transmission by pruning shears may be possible (Fig. 3B). During the course of the 2-year experiment, 4 of 14 $(28 \%)$ greenhouse test plants and 2 of 15 (13\%) outdoor test plants tested positive for $X$. fastidiosa. The apparent high percentage of positive test plants at the end of the experiment (Fig. 3B) was due to loss of plants to pocket gophers (Thomomys spp.; Fig. 3C). Specifically, by the end of the experiment, only three greenhouse test plants and four outdoor test plants survived, of which one greenhouse and two outdoor test plants were positive for $X$. fastidiosa. Test plants displayed the same seasonal trends in $X$. fastidiosa detection as needle-inoculated plants.

Over the course of the 2-year study, plant mortality was high and mortality of test plants was similar to that of needleinoculated plants (Fig. 3C). As stated above, most mortality was due to activity of pocket gophers in screen cages. This source of mortality likely acted independently of infection status. Mortality of plants held in the greenhouse was high after transplanting to the screen cage in spring 2008.

Incidence of $X$. fastidiosa in alfalfa. Of 3,849 alfalfa samples assayed over 3 years of study, only 6 were positive for $X$. fastidiosa. All six samples were collected during the summer in Fresno County. Two positive samples were from site A during summer 2005 and both were collected from the same quadrat. The other four positive samples were collected from site B during summer 2007 and were collected from the same quadrat.

Vector sampling in alfalfa. In total, 8,939 green sharpshooters were captured on yellow sticky traps during the course of the study. A single glassy-winged sharpshooter was captured on a sticky trap at site A in July 2008. Site A was the only site located within a known glassy-winged sharpshooter-infested zone. No red-headed sharpshooters were observed at any location throughout the study period.
There was no effect of year, county, number of cuttings, or number of irrigations on the number of green sharpshooters trapped (whole model, $F=2.48$, df $=6,4$, $P=0.20$ ), indicating that these variables do not explain variation in green sharpshooter abundance. Fields were cut approximately every 30 days starting in April and running through October, for an average of $6.6 \pm 0.4$ (mean \pm standard deviation $[\mathrm{SD}]$ ) cuttings per year and $7.4 \pm 0.6$ (mean $\pm \mathrm{SD}$ ) irrigations per year. To our knowledge, there was only a single insecticide application applied during the entire course of study. This occurred at site A in March 2006 and was an application of a pyrethroid that targeted alfalfa weevil.

The number of green sharpshooters trapped on field perimeters did not differ from the number trapped in the interior $(t$ $=1.80, \mathrm{df}=11, P=0.10)$, although abundance of green sharpshooters on field perimeters was generally greater than abundance in field interiors for all but a single field (Fig. 4A). The percentage of area covered by weeds was significantly greater on field perimeters than on field interiors (Fig. 4B, $t=3.0$, df $=7, P=0.02$ ). As with
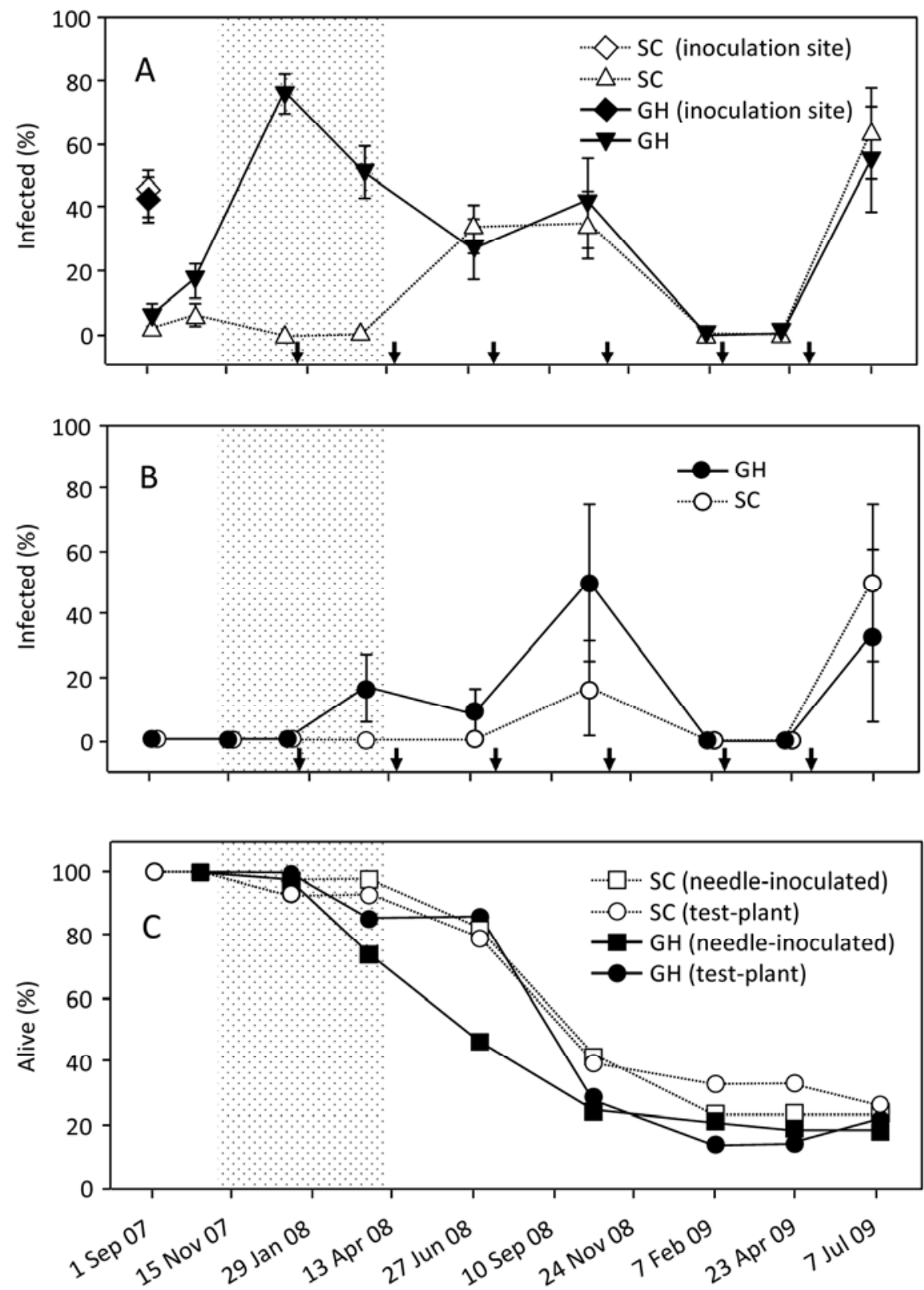

Fig. 3. Seasonal trends in Xylella fastidiosa detection. A, Percentage ( \pm standard error) of needleinoculated plants testing positive. Two groups of plants were followed: plants held outside in a screen cage (SC) during the entire course of the study and plants held in a greenhouse (GH) from 22 October 07 to 14 April 08. Shaded area indicates the time period during which greenhouse plants were indoors. On the first sampling date (5 September 2007), two stems per plant were tested: stems that received inoculations (inoculated stem) and stems distant from the inoculation site (unlabeled). B, Percentage of test plants testing positive. Cutting dates are indicated by arrows. C, Survival of needle-inoculated plants and test plants. Results are pooled for all cultivars. Percentages are based on the number of plants alive on a sampling date. 
the previous analysis, a single field differed from the overall trend. Specifically, at site C in 2008, more green sharpshooters were caught on traps on the field interior than on the perimeter (Fig. 4A). Likewise, site $\mathrm{C}$ in 2008 was the only field to have a greater percentage of weedy ground cover surrounding traps on the field interior than on the perimeter (Fig. 4B). The field sampled at site $\mathrm{C}$ in 2008 differed in one respect from all other fields, in that it was irrigated from the center rather than from the perimeter. These observations suggest that higher trap catches for traps on field perimeters than interiors was largely driven by the presence of weeds rather than green sharpshooters preferring field perimeters.

Simple regressions of number of green sharpshooters caught and weed ground cover surrounding a trap revealed a significant effect of weed ground cover on trap catch for five of eight site-year combinations (significant: site A-08, $F=$ 13.04, $\mathrm{df}=1,18, P=0.002$; site $\mathrm{C}-07, F$ $=4.55, \mathrm{df}=1,14, P=0.05 ;$ site $\mathrm{C}-08, F$ $=4.64, \mathrm{df}=1,18, P=0.05$; site E-2-07, $F=7.6$, df $=1,14, P=0.02$; and site E$08, F=14.34$, df $=1,18, P=0.001$; not significant: site B-07, $F=2.06$, df $=1$, $14, P=0.1736$; site $\mathrm{D}-07, F=0.08, \mathrm{df}=$ $1,14, P=0.78$; site E-1-07, $F=1.48, \mathrm{df}=$ $1,14, P=0.24)$. A multiple regression of site and weed cover nested within site further indicated a significant effect of site on trap catch $(F=17.35, \mathrm{df}=7,124$, $P<0.0001)$ and, within sites, a significant effect of weed cover surrounding a trap on trap catch (Fig. 4C; $F=7.33$, df = $8,124, P<0.0001)$.
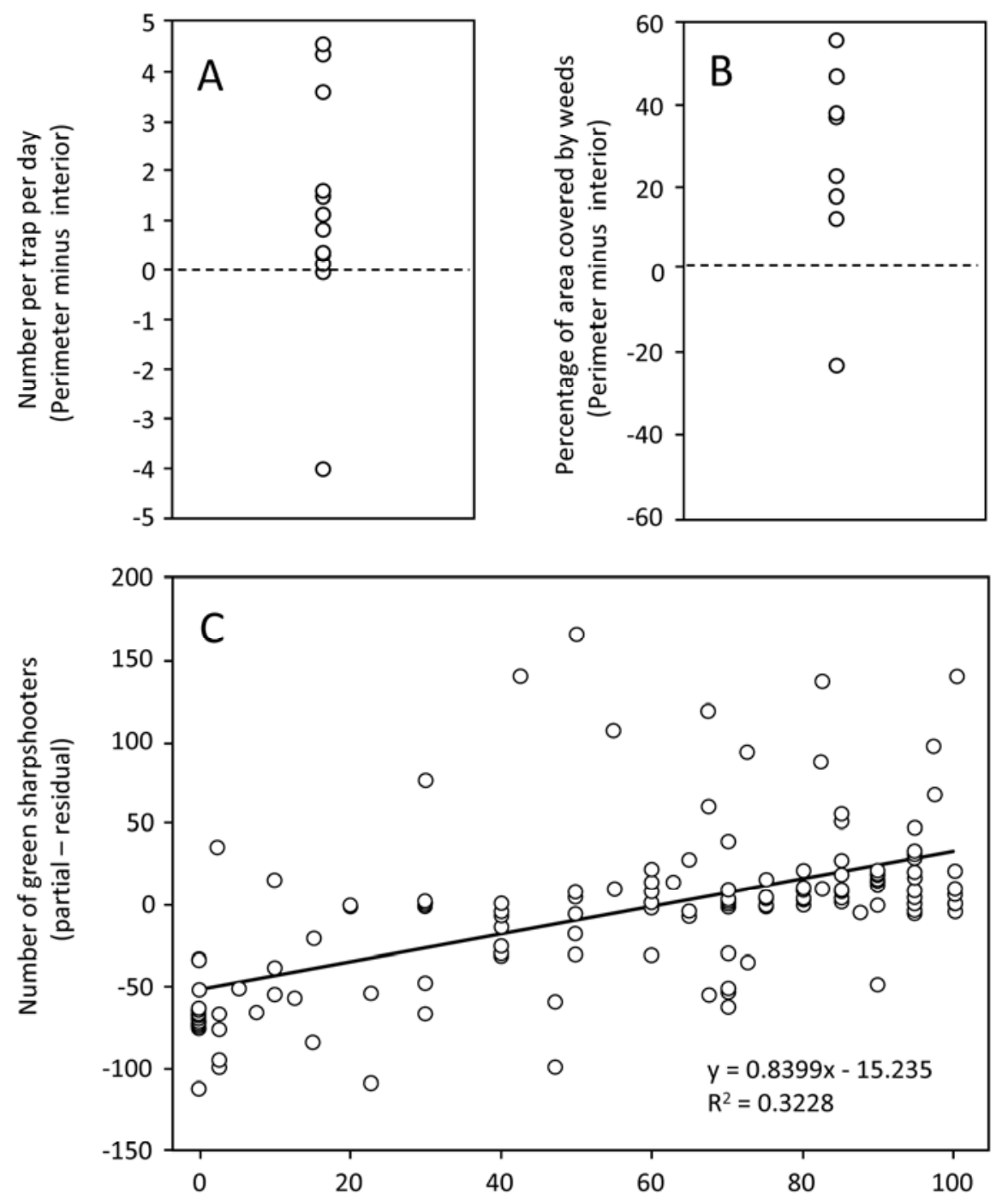

Area covered by weeds (\%)

Fig. 4. A, Difference in the number of green sharpshooters caught per trap for traps on the perimeter of alfalfa fields versus the interior. For each field, the mean number per trap for traps on field interiors was subtracted from the mean number per trap for traps on field perimeters. B, Difference in the percent area covered by weeds surrounding traps for traps on the perimeter of alfalfa fields versus the interior. For each field, the mean area covered by weeds for traps on field interiors was subtracted from the mean area covered by weeds for traps on field perimeters. C, Effects of area covered by weeds on trap catch with the effect of site removed.

\section{DISCUSSION}

The potential for alfalfa to serve as a source of vectors or inocula was assessed. In agreement with other studies $(25,42)$, the green sharpshooter was common in alfalfa fields but was most abundant in weedy sections (Fig. 4). Sampling of alfalfa fields found that incidence of $X$. fastidiosa in alfalfa was low. The results suggest that alfalfa fields may serve as a source of vectors but alfalfa plants do not appear to be an important source of inocula. Because green sharpshooter dispersal is described as local (25), a prerequisite for alfalfa fields to be a source of vectors is proximity to almond or grape plantings. Analysis of GIS maps on the distribution of almond, grape, and alfalfa plantings indicated that, statewide, 94,521 ha of almond and grape were within $1.6 \mathrm{~km}$ of an alfalfa field (Fig. 2). Thus, there is sufficient proximity of alfalfa fields to grape and almond plantings for movement of green sharpshooters from alfalfa fields to almond or grape plantings to be probable.

Monitoring of needle-inoculated alfalfa plants found seasonal trends in detection (Fig. 3A). Similar to our results with alfalfa, studies with grape found that infections were not detectable in May but were detectable in late summer (28). Likewise, acquisition of $X$. fastidiosa from almond by green sharpshooters declined from July to October (11). Such effects are likely due to changes in $X$. fastidiosa population with season. Thus, alfalfa is likely to be a poor acquisition host in winter and spring but potentially a good acquisition host in summer and fall. The probability that an infection in grape becomes chronic decreases the later in the year a plant is inoculated $(17,18)$. Thus, observations of low populations of $X$. fastidiosa in alfalfa plants in the spring may reduce its importance as an acquisition source for Pierce's disease strains of $X$. fastidiosa unless insects acquire $X$. fastidios $a$ in the fall and survive until the following spring. Effects of time of year on the probability that an infection becomes chronic in almond are less well understood. Regardless, Shapland et al. (50) identified several weed species found around almond orchards that had higher detection in the spring than in the summer. If acquisition in the spring is a key component to the probability that a vector eventually inoculates grape or almond, such weeds may be more important inocula sources than alfalfa.

We found that incidence of $X$. fastidiosa in alfalfa was approximately $0.5 \%$ during summer ( 6 positives out of 1,156 tested over 3 years). No $X$. fastidiosa-positive alfalfa samples were collected in spring, fall, or winter. Based on results with needle-inoculated plants (Fig. 3A), a lack of positive samples in spring and winter was expected. However, the lack of positive samples in fall was unexpected. Because incidence of $X$. fastidiosa was low in 
summer samples, it is possible that a lack of detection in fall samples occurred simply due to chance. Low incidence of $X$. fastidiosa in alfalfa may be attributed to feeding preferences of green sharpshooters. Purcell and Frazier (42) indicated that alfalfa should be considered an occasional host rather than a primary host of green sharpshooter and, as anticipated, trap catches of green sharpshooter were highest in weedy portions of the field (Fig. 4C). If green sharpshooters preferentially feed on weeds in alfalfa fields, spread of $X$. fastidiosa from alfalfa to alfalfa would be limited. Accordingly, incidence of $X$. fastidiosa in weeds found in alfalfa fields should be assessed to fully evaluate the inoculum potential of alfalfa fields.

From 1929 to 1950, alfalfa dwarf, a disease presumed to be caused by $X$. fastidiosa, was reported to severely affect stands of alfalfa in California (26,53). Alfalfa dwarf is no longer considered a threat to alfalfa production (20) and our observations of low incidence of $X$. fastidiosa in alfalfa are in accordance with this observation. The release of the alfalfa dwarf resistant or tolerant cv. California Common 49 in 1950 was probably a major factor in mitigating problems with alfalfa dwarf (32). However, to our knowledge, this cultivar is no longer widely planted and needle inoculation of contemporary cultivars indicate that they are suitable hosts for $X$. fastidiosa (Fig. 3A; 14,36) and, at least in the case of WL625HQ, infection appears to have deleterious effects on plant growth (14).

If contemporary cultivars are suitable hosts for $X$. fastidiosa, why has alfalfa dwarf not experienced a resurgence? A review of the literature provides some insight; of particular relevance are discussions on stand loss by authors in the 1930s and today. In the original description of alfalfa dwarf, Weimar (53) indicates that the impetus for investigating alfalfa dwarf was due to stand loss which limited the productive lifetime of a stand to 3 years rather than the desired 8 to 10 years. Alfalfa dwarf was eventually viewed as an important factor contributing to stand loss during this period (32). Putnam et al. (44) recently reviewed current practices and indicated that there is substantial stand loss over the first 3 to 4 years and recommends rotating to another crop at this time. Importantly, Putnam et al. (44) attributed stand loss to a host of factors (number of cuttings, traffic, summer heat, scald, winter flooding, cold winter temperatures, soil compactions, and soilborne diseases) but alfalfa dwarf is not mentioned and is not considered an economic problem in California (20). Thus, the situation regarding stand loss is the same now as it was from 1930 to 1950 but alfalfa dwarf is no longer considered to be an important factor. Acceptance that typical stand life times are 3 to 4 years rather than 8 to 10 years would decrease the importance placed on a disease that affects stand loss over 3 to 4 years. Additionally, movement of growers to a shorter rotation would reduce the inoculum potential of alfalfa fields because incidence would presumably be higher in older compared with younger fields. Thus, shorter rotations may have had a regional effect on incidence.

Test plants pruned after needleinoculated plants tested positive for $X$. fastidiosa, suggesting that mechanical transmission may be possible (Fig. 3B). Mechanical transmission has been reported for grape (33); thus, this possibility was not unexpected. However, because true control plants (uninoculated plants cut with cleaned shears) were not maintained, we cannot eliminate the possibility that infections in test plants were due to a mechanism other than mechanical transmission. For example, whiteflies and spider mites were observed on plants in the greenhouse and aphids were occasionally observed in screen cages. Although these insects are not reported to vector $X$. fastidiosa, we cannot rule out their involvement or the involvement of other agents that were not observed. Accordingly, we conclude that mechanical transmission may be possible and that more definitive tests are warranted.

One factor that should be included in studies on mechanical transmission is the effect of cut interval. For example, in our study, the cut interval was 3.7 times longer than that used by growers. Thus, one possibility that needs to be investigated is whether cutting on a grower's 28-day schedule (38) could eliminate infections before they become systemic. We found that only $4 \%$ of stems distant from inoculation sites tested positive for $X$. fastidiosa 47 days after inoculation (Fig. 3A). Thus, if it takes $>28$ days for infections to become systemic, growers may eliminate infections during harvest. We cannot evaluate this possibility because the first cut in our study occurred 173 days after the first inoculation although, in a related study, Almeida (1) found that cutting 56 days after inoculation did not eliminate infections in alfalfa. An additional factor that should be considered is distance of inoculation sites from pruning sites. This factor may be important because recent studies demonstrated that green sharpshooters prefer to feed at the base of alfalfa stems (15).

As expected, green sharpshooter abundance in alfalfa fields was high. However, we found no red-headed sharpshooters. Red-headed sharpshooters are reported to be less abundant than green sharpshooters and to prefer habitats that differ from those preferred by green sharpshooters (42). Insects were counted on yellow sticky traps and green sharpshooters were exceptionally abundant; therefore, it is not impossible that red-headed sharpshooters could have occasionally been caught but recorded as green sharpshooter due to their low density and similar appearance. A single glassy-winged sharpshooter was trapped at site A in Fresno County during 2008. Additional sweep net sampling at this site during the summer of 2008 caught another glassy-winged sharpshooter. Site A was the only site located within a glassywinged sharpshooter-infested area, and this finding confirms that glassy-winged sharpshooters may use alfalfa as a host. This site was located within a small agricultural region adjacent to an urban area, suggesting movement from ornamentals or backyard citrus into alfalfa.

In summary, the results confirm that alfalfa may play a role in the epidemiology of Pierce's disease and almond leaf scorch disease. Large areas of alfalfa are planted in proximity to almond and grape (Fig. 2D). Alfalfa harbors populations of green sharpshooters (Fig. 4) and can serve as a host for the glassy-winged sharpshooter. Further, alfalfa is a suitable host for $X$. fastidiosa (Fig. 3A). Combined, these features indicate that distancing almond and grape plantings from alfalfa could reduce risk of Pierce's disease and almond leaf scorch disease. An alternative strategy is weed control in alfalfa or shorter rotations to prevent establishment of weed populations. Our results and those of others $(25,42)$ lend strong support to the observation that the presence of green sharpshooters in alfalfa fields is due to lush weed growth rather than alfalfa plants. Thus, maintaining pure stands of alfalfa is likely to reduce green sharpshooter populations.

\section{ACKNOWLEDGMENTS}

We thank D. Dwyer, E. Felts, T. de la Torre, and S. Uchima for help with field and laboratory work; R. Yacoub for providing GIS maps; and R. Almeida and A. Purcell for valuable discussion and comments on an earlier draft of the manuscript. The project was supported by the University of California Pierce's Disease Grant Program (USDA/ CSREES supported) and the USDA-ARS.

\section{LITERATURE CITED}

1. Almeida, R. P. P. 2007. Role of alfalfa in the epidemiology of Xylella fastidiosa in California. Pages 231-234 in: Proc. Pierce's Dis. Res. Symp. California Department of Food and Agriculture, Sacramento.

2. Almeida, R. P. P., and Purcell, A. H. 2003. Biological traits of Xylella fastidiosa strains from grapes and almonds. Appl. Environ. Microbiol. 69:7447-7452.

3. Anonymous. 2002. Field seeds, grass seeds, hay, forage, and silage: 2002 and 1997. National Agricultural Statistics Service. http:// www.agcensus.usda.gov/Publications/2002/Vol ume_1,_Chapter_2_County_Level/California/s t06_2_026_026.pdf.

4. Anonymous. 2006. Annual pesticide use data. California Department of Pesticide Regulation. Environmental Monitoring and Pest Management Branch. http://www.cdpr.ca.gov/docs/ pur/purmain.htm.

5. Anonymous. 2007. Selected crops in California by section. California Department of Food and Agriculture. http://max.cdfa.ca.gov/pdcpgis/metadata/crops_pur.htm. 
6. Anonymous. 2008. 2007 California almond acreage report. National Agricultural Statistics Service. http://www.nass.usda.gov/Statistics_ by_State/California/Publications/Fruits and Nuts/200805almac.pdf.

7. Anonymous. 2008. California agricultural resource directory. California Department of Food and Agriculture. http://www.cdfa.ca.gov/ statistics/files/CDFA_Sec6.pdf.

8. Anonymous. 2009. 2009 almond almanac. Almond Board of California. http://www. almondboard.com/AboutTheAlmondBoard/ Documents/2009_AlmondBoard_Almanac.pdf.

9. Anonymous. 2008. California grape acreage 2007 crop. California Department of Food and Agriculture. http://www.nass.usda.gov/Statis tics_by_State/California/Publications/Fruits_ and Nuts/200704gabtb00.pdf.

10. Blua, M. J., Phillips, P. A., and Redak, R. A. 1999. A new sharpshooter threatens both crops and ornamentals. Calif. Agric. 53:22-25.

11. Cabrera-La Rosa, J. C., Johnson, N. W., Civerolo, E. L., Chen, J., and Groves, R. L. 2008. Seasonal population dynamics of Draeculacephala minerva (Hemiptera : Cicadellidae) and transmission of Xylella fastidiosa. J. Econ. Entomol. 101:1105-1113.

12. Chen, J., Civerolo, E. L., Jarret, R. L., Van Sluys, M.-A., and de Oliveira, M. C. 2005. Genetic discovery in Xylella fastidiosa through sequence analysis of selected randomly amplified polymorphic DNAs. Curr. Microbiol. 50:78-83.

13. Chen, J., Groves, R., Zheng, Y., Civerolo, E. L., Viveros, M., and Freeman, M. 2007. Colony morphology of Xylella fastidiosa almond leaf scorch strains. Can. J. Plant Pathol. 29:225-231.

14. Daugherty, M. P., Lopes, J. R. S., and Almeida, R. P. P. 2010. Strain-specific alfalfa water stress induced by Xylella fastidiosa. Eur. J. Plant Pathol. DOI: 10.1007/s10658-010-9598-

15. Daugherty, M. P., Lopes, J. Lopes, and Almeida, R. P. P. 2010. Vector within-host feeding preference mediates transmission of a heterogeneously distributed pathogen. Ecol. Entomol. DOI: 10.1111/j.1365-2311.2010. 01189. $\mathrm{x}$

16. Davis, M. J., Purcell, A. H., and Thomson, S. V. 1978. Pierce's disease of grapevinesisolation of causal bacterium. Science 199:7577.

17. Feil, H., Feil, W. S., and Purcell, A. H. 2003. Effects of date of inoculation on the withinplant movement of Xylella fastidiosa and persistence of Pierce's disease within field grapevines. Phytopathology 93:244-251.

18. Feil, H., and Purcell, A. H. 2001. Temperaturedependent growth and survival of Xylella fastidiosa in vitro and in potted grapevines. Plant Dis. 85:1230-1234.

19. Francis, M., Lin, H., Cabrera-La Rosa, J., Doddapaneni, H., and Civerolo, E. L. 2006. Genome-based PCR primers for specific and sensitive detection and quantification of $\mathrm{Xy}$ lella fastidiosa. E. J. Plant Pathol. 115:203213.

20. Frate, C. A., and Davis, R. M. 2008. Alfalfa diseases and management. Pages 155-174 in: Irrigated Alfalfa Management for Mediterranean and Desert Zones. C. G. Summers and D. H. Putnam, eds. Univ. Calif. Agric. Nat. Resour. Publ. 3512, Oakland.

21. Goodwin, P., and Purcell, A. H. 1992. Pierce's disease. Pages 76-84 in: Grape Pest Management. D. L. Flaherty, L. P. Christensen, W. T Lanini, J. J. Marois, P. A. Phillips, and L. T. Wilson, eds. University of California, Division of Agriculture and Natural Resources, Oakland.

22. Groves, R. L., Chen, J., Civerolo, E. L., Freeman, M. W., and Viveros, M. A. 2005. Spatial analysis of almond leaf scorch disease in the San Joaquin Valley of California: Factors affecting pathogen distribution and spread. Plant Dis. 89:581-589.

23. Hendson, M., Purcell, A. H., Chen, D., Smart, C., Guilhabert, M., and Kirkpatrick, B. 2001. Genetic diversity of Pierce's disease strains and other pathotypes of Xylella fastidiosa. Appl. Environ. Microbiol. 67:895-903.

24. Hewitt, W. B. 1958. The probable home of Pierce's disease. Plant Dis. Rep. 42:211-215.

25. Hewitt, W. B., Frazier, N. W., Freitag, J. H., and Winkler, A. J. 1949. Pierce's disease investigations. Hilgardia 19:207-262.

26. Hewitt, W. B., and Houston, B. R. 1941. Association of Pierce's disease of grapevines and alfalfa dwarf in California. Plant Dis. Rep. 25:474-476.

27. Hewitt, W. B., Houston, B. R., Frazier, N. W., and Freitag, J. H. 1946. Leafhopper transmission of the virus causing Pierce's disease of grape and dwarf of alfalfa. Phytopathology 36:117-128.

28. Hill, B. L. 2006. The effect of dormant season survival of Xylella fastidiosa in grapevines on Pierce's disease epidemics in California. Pages 276-279 in: Proc. 2006 Pierce's Dis. Res. Symp. T. Esser, ed. California Department of Food and Agriculture, Sacramento.

29. Hill, B. L., and Purcell, A. H. 1997. Populations of Xylella fastidiosa in plants required for transmission by an efficient vector. Phytopathology 87:1197-1201.

30. Hoddle, M. S., Triapitsyn, S. V., and Morgan, D. J. 2003. Distribution and plant association records for Homalodisca coagulata (Hemiptera: Cicadellidae) in Florida. Fla. Entomol. 86:89-91.

31. Hopkins, D. L. 1989. Xylella fastidiosa: xylem-limited bacterial pathogen of plants. Annu. Rev. Phytopathol. 27:271-290.

32. Houston, B. R. 1949. Dwarf resistant alfalfa. Calif. Agric. 3:3-10.

33. Krell, R. K., Boyd, E. A., Nay, J. E., Park, Y.L., and Perring, T. M. 2007. Mechanical and insect transmission of Xylella fastidiosa to Vitis vinifera. Am. J. Enol. Vitic. 58:211-216.

34. Ledbetter, C. A., Chen, J. C., Livingston, S., and Groves, R. L. 2009. Winter curing of Prunus dulcis cv. 'Butte,' P. webbii and their interspecific hybrid in response to Xylella fastidiosa infections. Euphytica 169:113-122.

35. Lin, H., and Walker, M. A. 1997. Extracting DNA from cambium tissue for analysis of grape rootstocks. HortScience 32:1264-1266.

36. Lopes, J. R. S., Daugherty, M. P., and Almeida, R. P. P. 2009. Context-dependent transmission of a generalist plant pathogen: host species and pathogen strain mediate insect vector competence. Entomol. Exp. Appl. 131:216-224.

37. Minsavage, G. V., Thompson, C. M., Hopkins, D. L., Leite, R. M. V. B. C., and Stall, R. E. 1994. Development of a polymerase chain reaction protocol for detection of Xylella fastidiosa in plant tissue. Phytopathology 84:456461.

38. Orloff, S., and Putnam, D. 2006. Cutting schedule strategies to maximize returns. In: Proc. Western Alfalfa and Forage Conf. University of California Cooperative Extension, Reno, NV.

39. Perring, T. M., Farrar, C. A., and Blua, M. J. 2001. Proximity to citrus influences Pierce's disease in Temecula Valley vineyards. Calif. Agric. 55:13-18.

40. Purcell, A. H. 1975. Role of blue-green sharpshooter, Hordnia circellata, in the epidemiology of Pierce's disease of grapevines. Environ. Entomol. 4:745-752.

41. Purcell, A. H. 1980. Environmental therapy for Pierce's disease of grapevines. Plant Dis. 64:388-390.

42. Purcell, A. H., and Frazier, N. W. 1985. Habitats and dispersal of the principal leafhopper vectors of Pierce's disease in the San Joaquin Valley. Hilgardia 53:1-32.

43. Purcell, A. H., and Saunders, S. R. 1999. Glassy-winged sharpshooters expected increase plant disease. Calif. Agric. 53:26-27.

44. Putnam, D. H., Orloff, S. B., and Teuber, L. R. 2008. Choosing an alfalfa variety. Pages 59-72 in: Irrigated Alfalfa Management for Mediterranean and Desert Zones. C. G. Summers and D. H. Putnam, eds. Univ. Calif. Agric. Nat. Resour. Publ. 3521, Oakland.

45. Ramsey, F. L., and Shafer, D. W. 2002. The Statistical Sleuth: A Course in Methods and Data Analysis. Duxbury Press, New York.

46. Redak, R. A., Purcell, A. H., Lopes, J. R. S., Blua, M. J., Mizell, R. F., III, and Andersen, P. C. 2004. The biology of xylem fluid-feeding insect vectors of Xylella fastidiosa and their relation to disease epidemiology. Annu. Rev. Entomol. 49:243-270.

47. Sanborn, R. R., Mircetich, S. M., Nyland, G., and Moller, W. J. 1974. "Golden death" a new leaf scorch threat to almond growers. Calif. Agric. 28:4-5

48. SAS. 2002. JMP Statistics and Graphics Guide. SAS Institute, Cary, NC.

49. Severin, H. H. P. 1949. Transmission of the virus of Pierce's disease of grapes by leafhoppers. Hilgardia 19:190-206.

50. Shapland, E. B., Daane, K. M., Yokota, G. Y., Wistrom, C., Connell, J. H., Duncan, R. A., and Viveros, M. A. 2006. Ground vegetation survey for Xylella fastidiosa in California almond orchards. Plant Dis. 90:905-909.

51. Sisterson, M. S., Chen, J. C., Viveros, M. A., Civerolo, E. L., Ledbetter, C., and Groves, R. L. 2008. Effects of almond leaf scorch disease on almond yield: Implications for management. Plant Dis. 92:409-414.

52. Sisterson, M. S., Yacoub, R., Montez, G., Grafton-Cardwell, E. E., and Groves, R. L. 2008. Distribution and management of citrus in California: Implications for management of glassy-winged sharpshooter. J. Econ. Entomol 101:1041-1050.

53. Weimer, J. L. 1931. Alfalfa dwarf, a hitherto un-reported disease. Phytopathology 21:71-75.

54. Weimer, J. L. 1937. Effect of the dwarf disease on the alfalfa plant. J. Agric. Res. 55:87-104.

55. Weimer, J. L. 1937. The possibility of insect transmission of alfalfa dwarf. Phytopathology 27:697-702

56. Wells, J. M., Raju, B. C., Hung, H. Y., Weisburg, W. G., Mandelco-Paul, L., and Brenner, D. J. 1987. Xylella fastidiosa: new-genus, newspecies, gram-negative xylem-limited fastidious plant bacteria related to Xanthomonas spp. Int. J. Syst. Bacteriol. 37:136-143. 